Мурашкін Михайло Георгієвич, доктор філософських наук, професор, Придніпровська державна академія будівниитва та архітектури, вул. Чернишевського, 24- $A$, Дніпро, Україна, 49000, https://orcid.org/0000-0001-7656-664X michailmurashkin@gmail.com

\title{
СТАН МИТЦЯ В ХУДОЖНІЙ КУЛЬТУРІ І МІСТИЦИЗМ (ОНТОЛОГІЧНИЙ АСПЕКТ)
}

Мета дослідження - розкрити в явищах буття подібного у «Стані Безсмертя» митця i містика. Методологічну основу дослідження склали загальнонаукові методи аналогії, компаративного аналізу, метод системноструктурного аналізу, принцип історизму, а також порівняльно-історичний підхід і метод герменевтичної критики містичних текстів, емпіричної базою дослідження $\epsilon$ західноєвропейський містицизм. Наукова новизна статті полягає у розкритті в явищах буття подібного у «Стані Безсмертя» митця і містика. Висновки. Явище подібного митця і містика - це стадія «визрівання» у творчому процесі, що зводиться до руйнації буття попередніх структур свідомості. Наступна стадія творчого процесу - це стадія «інсайту», де оновлюється буття структур свідомості. Але ця стадія з'являється декілька разів і при «визріванні» не має особливого вирішального значення. Цей інсайт розуміється як «Стан Безсмертя», тому що супроводжується цим станом. Також цей інсайт торкається значно ширшого, ніж конкретні завдання для творчості. Суб'єктивний фактор буття проявляється в неповторності особливостей стадії «визрівання», стадії, яка є обов'язковою в творчому процесі.

Ключові слова: стан митця; художня культура; Стан Безсмертя; інсайт; свідомість та самосвідомість.

Мурашкин Михаил Георгиевич, доктор философских наук, профессор, Приднепровская государственная академия строительства и архитектуры, ул. Черныпевского, 24-А, Днепр, Украина

Состояние художника в художественной культуре и мистицизм (онтологический аспект)

Цель исследования - раскрыть в явлениях бытия подобное «Состоянию Бессмертия〉 художника и мистика. Методологическую основу исследования составили общенаучные методы аналогии, компаративного анализа, метод системно-структурного анализа, принцип историзма, а также сравнительноисторический подход и метод герменевтической критики мистических текстов. Эмпирической базой исследования является западноевропейской мистицизм. Научная новизна статьи заключается в раскрытии в явлениях бытия подобного в «Состоянии Бессмертия» художника и мистика. Выводы. Явление подобного 
художника и мистика - это стадия «вызревания» в творческом процессе, сводящаяся к разрушению бытия предыдущих структур сознания. Следующая стадия творческого процесса - это стадия «инсайта», где обновляется бытие структур сознания. Но эта стадия повторяется несколько раз и при «вызревании» не имеет особого решающего значения. Этот инсайт понимается как «Состояние Бессмертие», потому что сопровождается этим состоянием. Также этот инсайт касается значительно более широкого, чем конкретные задачи для творчества. Субъективный фактор бытия проявляется в неповторимости в особенности стадии «вызревания», стадии, которая является обязательной в творческом процессе.

Ключевые слова: состояние художника; художественная культура; Состояние Бессмертия; інсайт; сознание и самосознание.

Murashkin Mykhailo, Doctor of Philosophy, Professor, Prydniprovska State Academy of Civil Engineering and Architecture, 24a, Chernyshevskoho St, Dnipro, Ukraine

The state of the artist in artistic culture and mysticism (ontological aspect)

The purpose of the article is to reveal the state similar to artist's or mystic's "State of Immortality" in the phenomena of existence. The research methodology consisted in general scientific methods of analogy, comparative analysis, the method of system-structural analysis, the principle of historicism, as well as the comparative historical approach and the method of hermeneutic criticism of mystical texts. The empirical base of the study was West European mysticism. The scientific novelty of the work lies in the discovery of signs of the state similar to artist's and mystic's "State of Immortality" in the phenomena of existence. Conclusions. The phenomenon of a similar artist and mystic is the stage of "maturation" in the creative process, which amounts to the destruction of the existence of former structures of consciousness. The next stage of the creative process is the "insight" stage, where the existence of the structures of consciousness is renewed. However, this stage is repeated several times and is not of particular importance in the process of "maturation". This insight is understood as the "State of Immortality" because it is accompanied by this state. Also, this insight is concerned with something wider than the specific tasks for creativity. The subjective factor of existence is reflected by the uniqueness, in particular, of the "maturation" stage, the stage that is obligatory in the creative process.

Key words: state of the artist; artistic culture; State of Immortality; insight; consciousness and self-consciousness.

Вступ. Предмет наших досліджень - це буття певного стану свідомості вищого рівня (Ревонсуо, 2013) з урахуванням того, що «Стан Безсмертя» - вищий рівень прояву свідомості. Розуміння вищого рівня є від того, що сама людина, переживаючи ці стани свідомості, фіксує в своєму суб'єктивному світі те, що вищого за цей стан нічого немає і не може бути. Цей стан має назву «Стан Безсмертя», де буття Безсмертя, буття Самодостатності й буття Бога є синонімами. Цей стан ми беремо на розгляд, тому що він має риси подібності у досвіді містика i митця, що відповідає предмету наших досліджень. Як містик, так і митець 
переживають цей стан не тільки в своїх компенсаторних реакціях на страх смерті, але й у своєму творчому процесі.

Природа «Стану Безсмертя» компенсаторна. Це компенсаторний феномен в творчому процесі самодостатнього характеру. Через це в назву цього феномена можна включати i таке поняття як «самодостатність». Розглянемо буття самодостатності. Адже перший синонім «Стану Безсмертя» є самодостатність.

Самодостатність. Природа феномена самодостатності, який ми досліджуємо, $\epsilon$ компенсаторною. Людина первісно має відчуття неповноцінності, недостатності (Адлер, 1997). Ці неповноцінність і недостатність природжені, або пов'язані 3 аномаліями розвитку (Кэлвин, Гарднер, 1997). Але 3 роками недостатність компенсується відчуттям самодостатності, переживанням стану самодостатності. У людини 3 віком, 3 літами, у 40-50 років розлад, який дає недостатність, стає м'якшим і без лікування; проходить спонтанно ремісія (Бурно, 1989).

Другий синонім «Стану Безсмертя» $\epsilon$ «Бог». Тобто до поняття «Стан Безсмертя» можна прикладати і поняття «Бог». Це пов'язане 3 тим, що даний феномен досконало описується в Святому Письмі: у Ведах, Авесті, Трипітаці, Дао де цзін, Біблії, у Корані. Також «Стан Безсмертя» досконало описаний в релігійній і містичній літературі, а митець намагається наслідувати, імітувати Бога (Рыков, 2007). Саме ж слово «Бог» має значення «доля», добра доля, щаслива доля, щастя (Потебня, 1989). Бог - це те, що дає долю щастя. Тут щастя як трясця: кого схоче, на того й нападе (Потебня, 1989), що вказує на спонтанність процесу. Тобто «Бог» - це «щастя». А щастя - це самодостатній стан життя (Гусейнов, 2010).

Третє поняття або третій синонім, який можна вживати у назві феномена, який ми розглядаємо, - це «Безсмертя». Тут безсмертя розуміється як стан.

«Стан Безсмертя». Безсмертя можна розуміти як перетворення (Огурцов, 2010). Людина може в екстатичному спогляданні пережити «Стан Безсмертя» (Никонов, 2006). Безсмертя такого роду, як екстатичні спалахи, які здаються нам такими, що лежать по той бік часу і вище часу, коли охоплює відчуття чистої бескінечності (Ламонт, 1984). Екстатичні стани сприймаються як містичне відчуття причетності до вічності (Третьяков, 2006).

Коли присутній «Стан Безсмертя», то людині: по-перше, смерть здається неможливістю (Джем, 1993), по-друге, абсолютно нема страху ні перед чим (Мурашкин, 2006), страх тільки затемнює (Кришнамурти, 1999), і по-третє, це проходить як екстатичні спалахи, які здаються нам такими, що лежать по той бік часу і вище часу, коли охоплює відчуття чистої бескінечності (Ламонт, 1984). Тобто «Стан Безсмертя» часто констатують як екстатичний стан, екстаз. Екстаз це вищий ступінь захоплення, запалу. Однак у всіх цих випадках слово «екстаз» вживається як узагальнений образ, навіть в силу того, що самі екстази бувають різного характеру.

Екстаз - зміщення в область захоплення, запалу. Екстаз - це оціпеніння як компенсаторна реакція на неправильні захоплення людини, коли настає захоплення правильним, ідеалом, зразком. Коли екстаз переживається людиною як вищий ступінь запалу, який доводить до оціпеніння, то можна говорити вже не про екстаз, а про транс, про певний вид трансу. Адже сам транс також буває різного роду. Однак $є$ транс, як і екстаз, який супроводжується оціпенінням. 
В такому випадку транс - це оціпеніння як компенсаторна реакція на неправильні дії. При цьому втрачається орієнтація в часі (Забияко, 2009), що характерно и для переживання «Стану Безсмертя».

Екстаз супроводжує творчий процес. Творчий же процес як отримання нових значень розмежовується на такі стадії: підготовка, визрівання, натхнення, або осяяння і перевірка істинності (Роменець, 2004). Тобто натхнення і осяяння можуть бути однією стадією (Вудвортс, 1981). А може бути так, що натхнення переходить в екстаз в момент кульмінації творчого процесу - при осяянні (Ильин, 2011). Тут екстаз розуміється як супроводжуючий творчий процес. Коли ми кажемо про творчий процес і особливо про його стадію інсайту, тобто про осяяння як кульмінаційний момент, то цей кульмінаційний момент може бути і в стадії «визрівання». У процесі довгого визрівання концепції інсайти можуть виникати декілька разів, але не мати вирішального значення для розбудови концепції в цілому (Ильин, 2011). Вирішального значення може не мати і натхнення зі своїм переходом в екстаз. Натхнення може не давати успіху в творчості. Натхнення може бути лише поштовхом, стимулом до діяльності; більш того лише стимулом до діяльності, а не самою діяльністю. Натхнення не робить результатів, плодів творчості. Людина в творчому відношенні безплідна може переживати натхнення, екстаз. Тобто натхнення може проминути без творчих результатів. Можна зазнати натхнення i екстазу без усілякого зовнішнього сліду. Зовсім не геній може пережити такі ж натхнення і екстаз, як і геній. Натхнення і екстаз не означають змістовності, яка відділяє істину від хибності, добро від зла. Натхнення і екстаз можуть проходити без наявності певного змісту (Гончаренко, 1991). Та і сам інсайт, саме осяяння, може не мати вирішального значення (Ильин, 2011). А такі феномени вже нагадують «Стан Самодостатності» як «Стан Бога», «Стан Безсмертя». Адже самодостатність не має змістовності (Ясперс, 1997). Тут і відчуття щастя беззмістовне (Ясперс, 1997). А Бог, «Стан Бога»- це щастя (Потебня, 1989). Тобто людина може мати певні вищі стани свідомості й пережити вищі відчуття безсмертя і усвідомлення вічності життя, відчуття, які неможливо визивати за своїм бажанням (Ревонсуо, 2013), і які суб'єктивно для конкретної людини будуть давати розуміння, що вищого за це нічого не може бути. Цей вищий стан свідомості розуміється як «Стан Безсмертя» (Ревонсуо, 2013). Синонімом цього стану є «Стан Самодостатності», де самодостатність беззмістовна. Ще одним синонімом «Стану Безсмертя» $\epsilon$ «Стан Бога» як стан щастя, коли Господь зустрічає з долею щасливою (Українська народна обрядова поезія, 2006). При розгляді стану щастя як «стану потоку» (Прохоров, Валиуллина, Габдреева, Гарифуллина, Менделевич, 2011) ми бачимо подібні риси при деяких видах екстазу. В свою чергу розглядаючи екстаз як загострену форму уваги, ми виходимо на розуміння медитації, медитативних станів, які за суб'єктивним змістом предстають як «Стан Безсмертя». Але треба розуміти і важливу різницю. Вона полягає в тому, що медитація - це вправи, а «Стан Безсмертя» - чисто спонтанний феномен. Чиста спонтанність присутня i y містика як «містичне натхнення» (Рибо, 2002) і у митця (Валери, 1976).

Безумовно, ракурс суб'єктивної онтології підштовхує сказати дещо про онтологічний аспект об'єктивної реальності, щоб вписати розглянутий «Стан 
Безсмертя», а точніше «Стан Безсмертя Самодостатнього Бога», в об’єктивні реалії, бо, на перший погляд, це може виглядати, як гра слів. Але це може сказати наука зі своєю верифікацією, зі своїми перевірками на об'єктивність.

Аналіз досліджень і публікацій показав наявність матеріалів 3 цього приводу. Предмет наших досліджень під терміном «Стан Безсмертя» вводится за документальними фактами людей, які відчували безсмертя (Ревонсуо, 2013), де смерть представлялась неможливою (Джемс, 1993), і було усвідомлення життя вічного (James, 1902). Тут подібність станів містика і митця ми бачимо у містицизмі (Кришнамурти, 1999) і в оцінюванні станів містицизму як творчих станів митця (Латьенс, 1993). Буття подібності стану містика і митця пов'язане з існуванням арефлексивного в людині (Дубровский, 1983), а також «каталептичної свідомості» (Элиаде, 2009), де проходять процеси компенсаторного характеру (Адлер, 1997).

Виділення невирішених раніше частин загальної проблеми. Постановка проблеми полягає у тому, щоб знайти подібність у бутті митця художньої культури і в містицизмі.

Мета дослідження - розкрити у явищах буття подібного в «Стані Безсмертя» митця і містика.

Серед методів дослідження: принципи системно-структурного аналізу, порівняльно-історичний підхід і метод герменевтичної критики містичних текстів. Емпіричної базою дослідження є західноєвропейський християнський містицизм.

Виклад основного матеріалу. Щодо «Стану Безсмертя» бажано почати 3 пояснень того, що $є$ онтологією, тому що ми розглядаємо онтологічний аспект предмета наших досліджень.

«Стан Безсмертя» як предмет наших досліджень розглядається в онтологічному аспекті. Тому зробимо певний екскурс в онтологію. Розкриємо основні поняття i прописні істини онтології як філософської дисципліни з орієнтацією на предмет наших досліджень.

Онтологія - філософське вчення про буття як таке. Поняття «онтологія» було введене Гокленіусом у XVII ст.

Антична філософія. В античній філософії буття розглядала онтологія елеатів, елейська школа. Так, Парменід розрізняв буття чуттєве і буття істинне. Аристотель шукав сутність у матеріальному бутті. Опис «Стану Безсмертя» ми можемо бачити в містиці, коли розглядається «чисте» буття як суб'єктивне переживання. Яскраві описи «Стану Безсмертя» ми можемо бачити у філософії Плотіна.

Середньовічна філософія. У середньовічній філософії Абсолютне буття ототожнюють із Богом. Тут «Стан Безсмертя» представлений у середньовічному релігійному містицизмі.

Філософія Нового часу. Філософія Нового часу орієнтується на науку. I тому вона вчення про буття відсторонюе від теології. Спіноза в своїй онтології ототожнює Бога і Природу.

Класична німецька філософія. Кант не ставить онтологію поза принципами розуму. Фіхте, Шеллінг, Гегель стверджують, що буття є результатом розвитку мислення. Тут мислення виявляе свою тотожність із буттям. В класичній 
німецький філософії місце «Стану Безсмертя» знаходиться, коли мова йде про містицизм.

Сучасна філософія. Позитивізм. Позитивізм відкидає онтологію як ненаукове знання. 3 об'єктивною онтологією відкидається і суб'єктивна онтологія, а разом 3 нею - і всілякі суб'єктивні переживання й стани як те, що є ненауковим, тому що не може бути верифікованим. Разом 3 цим відкидається і «Стан Безсмертя» як явище, яке не може бути перевірене.

Екзистенціалізм. Гайдеггер показує, що буття треба осмислювати через унікальність ситуації людської присутності. Сартр і Ясперс розуміють буття як неподільну єдність суб'єкта й об'єкта. Ця єдність лежить в основі свободи і відповідальності людини. В екзистенціалізмі при описах суб'єктивного світу людини чітко проглядається і опис «Стану Безсмертя».

Марксизм. Онтологія марксизму розкриває форми руху матерії, розкриває розуміння суспільного буття. Марксизм говорить про онтологію діяльності як спосіб буття людини. У цій філософії «Стан Безсмертя» підпадає під критику при розгляді різних містичних вчень як певні суб'єктивні переживання людини, не адаптованої до умов життя.

Посткласична філософія. У посткласичній філософії в онтологічне, тобто буттєве, входить і суб'єктивне, входить людська індивідуальність. При описах людської індивідуальності можна бачити і описи стану, який іменується «Стан Безсмертя».

Буття - це існування, яке виражається зв’язкою «Є». Коли буття розуміється як існування, як те, що є, то воно, це буття, стосується будь-чого, будь-яких речей. Таке буття беззмістовне, абстрактне. Воно байдуже до того, до чого воно застосується. Це «чисте буття». «Стан Безсмертя» має відношення якраз до «чистого буття» як не конкретного суб’єктивного переживання.

Коли є визначене буття, «ось це» (ця скеля, або цей камінь), то це називається «наявне буття». Тут, на перший погляд, нема місця для «Стану Безсмертя». «Стан Безсмертя» $є$ глибоко суб'єктивним буттям конкретного індивіда.

Буття розуміють як безпосередню дійсність, яка ще не роздвоєна на явище і сутність. 3 цієї безпосередньої дійсності починається пізнання. Тут сутність спочатку прихована. Вона спочатку не дається для пізнання. За Гегелем, буття i сутність розрізняються. Суб'єктивне буття «Стану Безсмертя»- невід'ємне переживання людини. Тому його сутність $є$ предметом наукових дисциплін.

Структура буття. Структура буття подається такими категоріями: якістькількість-міра. Ці категорії можна вживати і при розгляді «Стану Безсмертя». Тут міра торкається певних якостей людини. Коли якась якість перекриває повністю протилежну якість, то включаються компенсаторні механізми, які встановлюють рівновагу протилежностей. I ця рівновага може переживатися як «Стан Безсмертя».

Буття розуміється як протилежність свідомості (буття як матерія). Тут ми бачимо опозиційну пару: буття i свідомість. Буття (матерія) незалежне від свідомості. Людина охоплює буття своєю діяльністю. Але людина може деякий 
час знаходитися і поза своєю діяльністю. «Стан Безсмертя» має більш інтенсивний свій прояв якраз, коли людина не діє.

Небуття - заперечення буття. Небуття - це не існування. За Гегелем це ніщо. Ніщо беззмістовне як i чисте буття, коли від певної речі відокремлюються всі властивості, а залишається лише те, що вона є; ця річ лише є. Ніщо і чисте буття тотожні. Але вони і протилежні, адже фіксують відмінність між існуючими чи неіснуючими речами. В «Стані Безсмертя» людина переживає небуття, тому що цей стан супроводжується руйнацією попередніх структур свідомості, тих структур, які вже віджили своє і не дають людині адекватно реагувати на змінений світ. Це особливо можна бачити в містичній культурі, де символічна смерть є знаком для досвіду руйнації попередніх структур свідомості (Аверинцев, 2010). При руйнації попередніх структур свідомості людина може переживати небуття, ніщо, пустотність, порожнечу. Це дуже ретельно описано в буддизмі, в таких його містичних напрямках, як дзен-буддизм і чань-буддизм. Також досконалий опис цього ми зустрічаємо в даосизмі.

Та чи інша річ виникає із зникнення попередніх утворень. Наприклад, брунька зникає, коли розпускається квітка. Квітка зникає 3 появою плода. «Стан Безсмертя» зникає, коли людина відчуває страх смерті. «Стан Безсмертя» є компенсацією страху смерті.

Кожне наступне утворення $є$ запереченням, небуттям попереднього утворення. Буття і небуття - це моменти становлення. Буття і небуття «Стану Безсмертя» - це моменти становлення в людині особистості.

Отже. Буття - це філософська категорія, що означає: все, що реально існує. Реальність, яка існує об’єктивно, поза і незалежно від свідомості людинице об'єктивне буття. Реальність як прояв свідомості людини, прояв людського духу - це суб'єктивне буття. У цьому суб'єктивному бутті людського духу $€$ й існування «Стану Безсмертя» при роботі компенсаторних процесів.

Форми буття: буття речей і процесів; буття духовного (ідеального); буття людини; буття соціальне. «Стан Безсмертя» ми відносимо до буття людини, а також до буття духовного (ідеального). Особливо якщо це торкається мистецтва.

Субстанція - це загальна первинна основа всіх речей. Субстанція є сутністю всіх речей. Субстанція нестворювана і незнищувана. Субстанція є причина самої себе й основа всіх змін. Матерія субстанціональна, а свідомість не субстанціональна. Тому «Стан Безсмертя» як певний прояв свідомості $є$ не субстанціональним станом.

Матерія - це філософська категорія для означення об'єктивної реальності, яка дана людині у відчуттях, яку людина намагається пізнати, але при цьому матерія існує незалежно від самої людини. Існувати - значить бути об’єктивною реальністю. Матерія розуміється як сутність, як субстанція, яка лежить в основі єдності усього. Структурність є властивістю матерії. Структурність матерії характеризує їі стан 3 точки зору перервності й неперервності. «Стан Безсмертя» як стан свідомості $\epsilon$ певною властивістю високоорганізованої матерії. Високоорганізованою матерією $є$ людський мозок. Отже, «Стан Безсмертя» як стан свідомості є властивістю людського мозку. 
Види матерії: речовина і поле. Речовина - все те, що має в основному механічну масу спокою. Поле - це вид матерії, який не має маси спокою.

Рух є спосіб існування матерії. Простір і час $є$ форми існування (буття) матеріальних систем. Простір і час існують об'єктивно і незалежно від свідомості. Простір і час не існують незалежно від матерії. Простір - це форма буття матерії. Простір характеризується протяжністю, структурністю. Простір характеризується співіснуванням і взаємодією елементів в тих чи інших матеріальних системах. Час - це форма буття матерії. Час виявляє тривалість існування матерії, матеріальних об'єктів. Час виявляє послідовність зміни станів у розвитку тих чи інших матеріальних систем. В «Стані Безсмертя» у людини втрачається орієнтація в часі (Забияко, 2009). Час зупиняється.

Концепції часу. Є дві концепції часу: динамічна і статична. Динамічна концепція часу. Динамічна концепція часу говорить, що є минуле, теперішнє і майбутнє. Існують події лише теперішнього часу. Минулого буття немає. Воно пішло в небуття, залишивши лише відбиток у теперішньому. Майбутніх подій не існує. С лише їхні передумови. Статична концепція часу. Статична концепція часу говорить, що минуле, теперішнє і майбутнє реально існують одночасно. Не існує поділу на минуле, теперішнє i майбутнє. I динамічна, і статична концепції часу розглядають об'єктивну реальність, певним чином торкаючись суб' єктивного при умові, що людина знаходиться в стані повсякденної свідомості. «Стан Безсмертя» є особливою суб'єктивною реальністю, коли людина знаходиться в трансі певного характеру. Тому тут сприйняття людиною часу $є$ зміненим сприйняттям.

Властивості простору і часу. До загальних властивостей простору і часу відносяться: об'єктивність і незалежність від свідомості людини; їх абсолютність як атрибутів матерії; нерозривний зв'язок простору і часу між собою, а також 3 рухом матерії. Простір - це протяжність (рядопокладання і співіснування), зв'язність, неперервність. Час - це тривалість, одномірність, асиметричність, незворотність. У суб’єктивній реальності «Стану Безсмертя» людина знаходиться поза простором і часом (Ламонт, 1984). Простір зникає, а час зупиняється. Тут мова йде не про об'єктивні простір і час, а про суб'єктивне сприйняття простору і часу, про психологічні простір і час.

Суб'єктивна онтологія. Свідомість. Свідомість - це властивість високоорганізованої матерії. Свідомість - це вища форма відображення, ідеальний образ матеріального світу. Свідомість $є$ продуктом суспільноісторичного розвитку. Свідомість є регулятором цілеспрямованої діяльності людини 3 втілення свого ідеалу безпечного майбутнього стану для себе і для інших. Отже, свідомість - це прояв людського духу, який пов'язаний із пізнанням. Тут пізнання робить реальність відомою, робить зміст цієї реальності відомою. При цьому реальність приймає предметно-мовну форму знання. У випадку «Стану Безсмертя» як певного зміненого стану свідомості ми не бачимо повної участі цього стану в пізнавальних процесах. Це пов’язане з тим, що «Стан Безсмертя» насамперед, компенсаторна реакція.

Свідомість опредметнюється опосередковано у знанні. А от «несвідомий» прояв духу опредметнюється безпосередньо у знанні. Безпосередньо у знанні 
опредметнюється і «Стан Безсмертя», тому що це «несвідомий» прояв духу. У нормальному стані у людини компенсація несвідома (Юнг, 1995). А «Стан Безсмертя» пов’язаний з компенсацією як ії фактична сутність.

Свідомість $є$ феномен діяльності, а не субстанційності; феномен не субстанційний. Тобто свідомість здійснюється в своїх інтенціях. Більш того свідомість має трансцендентальну спрямованість на зовнішній світ, у всіх своїх інтенціях на цей зовнішній світ. Саме слово «трансцендентальне», а від нього і «трансцендентне» в своїх коренях мають слово «транс» (Пустоваров, 2005, 28). Отже, «Стан Безсмертя» як певний вид трансу входить в коло станів людської свідомості.

Опредметнено-мовні значення є результатом проведення свідомістю своїх інтенцій на зовнішній світ. Тут опредметнено-мовні значення набувають онтологічного статусу об'єкта, об'єкта матеріального або ідеального (наприклад, скульптура). Свідомість спрямовує себе на реальний світ в пізнавальному напрямку, тобто пізнавально. Свідомість трансформує цей реальний світ в ідеальний світ. Свідомість зводить натуралістичність реального світу, трансформуючи іï в ідеальний світ. Свідомість також зводить психологічні прояви «несвідомого», теж трансформуючи їх в ідеальний світ. Трансформується в ідеальний світ і «Стан Безсмертя» в культурі містицизму та мистецтва, у містика та митця.

Свідомість - це прояв людської суспільної життєдіяльності. Тому свідомість має суспільний характер. Суспільний характер свідомості проявляється у таких формах, як філософія, релігія, наука, мистецтво, мораль. Свідомість опосередкована, теоретична. Тобто свідомість - це і мислення. Мислення не спрямоване на саме себе. Отже мислення - це опосередкована теоретична свідомість, яка спрямована не на саму себе, а на предметний зовнішній світ. Розум це також теоретична свідомість, яка тотожна тим чи іншим закономірностям, притаманним об’єктивному світу. Але «Стан Безсмертя» є самодостатнім станом, коли потреби в розумінні немає, як і ніякої іншої потреби, а є процес розпаду неправильного розуміння.

Розсуд і здоровий глузд. Розсуд треба розуміти як певне логічне міркування, а здоровий глузд - як певне життєво-практичне міркування. I мислення, і розум, і розсуд, і здоровий глузд - все це вияви свідомості. Але «Стан Безсмертя» також $\epsilon$ вияв свідомості, коли розум, розсуд і здоровий глузд не на правильному шляху і мають бути зміненими.

Самосвідомість - це свідомість, у якої пізнавальна активність спрямована на саму себе. Наслідком самосвідомості $\epsilon$ те, що людина вирізняється зі світового загалу. Також наслідком самосвідомості $є$ те, що людина може поглянути на себе «ззовні». Завдяки самосвідомості внутрішній світ людини актуалізує екзистенцію, характеристиками якої $є$ трансцендентально-унікальні стани індивіда. «Стан Безсмертя» якраз і відноситься до цих трансцендентально-унікальних станів.

Позасвідомість - це реальність психічного життя людини, що протистоїть свідомості. Позасвідомість існує за межами свідомості. Позасвідомість спонтанно представляється (проявляється) в свідомості. Але позасвідоме може взагалі не проявлятися в свідомості. За І. Кантом, позасвідоме пов’язане 3 інтуїцією. 
Інтуїтивні прозріння в творчому процесі часто супроводжуються переживаннями, схожими зі «Станом Безсмертя».

Свідомість формується під впливом соціального середовища, а позасвідомість дається людині від народження. Імпульси позасвідомості постійно «атакують» свідомість, але розуміння реалій суспільного життя не дають людині можливості втілити ці імпульси в життя. І виникає процес витіснення, як це помітив Зигмунд Фрейд. Імпульси позасвідомого повертаються назад до свого джерела. Але ці імпульси можуть сублімувати. Сублімація - це коли імпульси позасвідомого виражаються символами в формах культури, в іï артефактах. Символічне вираження має і «Стан Безсмертя».

Підсвідоме і надсвідоме. У позасвідомому розрізняють підсвідоме і надсвідоме. Підсвідоме - це сновидіння, психічні травми, комплекси. Надсвідоме - це інтуїції зрілої особистості, їі творчий процес. Тут людина в творчості розкриває свої глибинні можливості в інтуїціях, які можуть супроводжуватись «Станом Безсмертя».

Позасвідоме - морально амбівалентне, коли вчинок людини проходить поза іiї свідомістю. Несвідоме - інфантильна свідомість, стан непроявленого в людині, коли людина, оцінюючи себе 3 морального, ціннісного боку, робить несвідомий вчинок. «Стан Безсмертя» $є$ також інфантильною свідомістю, коли страх смерті не долається свідомою вольовою напругою, а має прояв компенсаторних механізмів подолання проблеми.

Самосвідомість особистості. Самосвідомість особистості - це усвідомлення людиною своєї специфічності, усвідомлення своєї особистісної специфіки. Самосвідомість виражає сутність внутрішньо-глибинного світу особистості.

Особистість у своїй самосвідомості сприймає себе як суспільно значущу цілісність. При цьому людина бачить в собі свою неповторну індивідуальність. Вона сприймає свої прояви як прояви творця самих суспільних відносин. Адже самосвідомість особистості взагалі має вияв лише в процесі суспільних взаємовідносин. Самосвідомість особистості формується відповідно до індивідуально-суспільних ідеалів. При цьому формується як самопізнання людини, включаючи в себе як самооцінку, так і ii саморегулювання. Йде також формування емоційно-ціннісного ставлення людини до самої себе. Тут $є$ і емоційно-ціннісне ставлення людини до свого стану, такого як «Стан Безсмертя». Цей стан має спонтанну природу. Тому людина оцінює причини появи в собі «Стану Безсмертя». Вона може розуміти цей стан як щось надприродне. Але вона може розуміти цей стан як прояв певних природних сил людини.

Наукова новизна статті полягає у розкритті у явищах буття подібного у «Стані Безсмертя» митця і містика.

Висновки. Явище подібного митця і містика - це стадія «визрівання» у творчому процесі. Стадія «визрівання» у творчому процесі зводиться до руйнування буття попередніх структур свідомості. Наступна стадія творчого процесу - це стадія «інсайту», де оновлюється буття структур свідомості. Але ця стадія з'являється декілька разів і при «визріванні» не має особливого вирішального значення. Цей інсайт розуміється як «Стан Безсмертя», тому що 
супроводжується цим станом. Також цей інсайт торкається значно ширшого, ніж конкретні завдання для творчості.

Суб’єктивний фактор буття проявляється в неповторності особливостей стадії «визрівання», стадії, яка є обов'язковою в творчому процесі.

\section{Список використаних джерел}

1. Аверинцев С. С. Мистика. Новая философская энциклопедия. В 4 т. Т. 2. Москва : Мысль, 2010. С. 579.

2. Адлер А. О нервическом характере. Санкт-Петербург: Университетская книга, 1997. С. 113.

3. Бурно М. Е. Терапия творческим самовыражением. Москва: Медицина, 1989. C. 58-210.

4. Валери П. Об искусстве. Москва : Искусство, 1976. С. 406.

5. Вудвортс Р. Этапы творческого мышления. Хрестоматия по общей психологии. Психология мышиления. Москва : Изд-во Моск. ун-та, 1981. С. 255-257.

6. Гончаренко Н. В. Гений в искусстве и науке. Москва : Искусство, 1991. С. 246-247.

7. Гусейнов А. А. Счастье. Новая философская энџиклопедия. В 4 т. Т. 3. Москва : Мысль, 2010. С. 686.

8. Джемс В. Многообразие религиозного опыта. Санкт-Петербург : Андреев и сыновья, 1993. С. 306.

9. Дубровский Д. И. Проблема идеального. Москва : Мысль, 1983. C. $85-100$.

10. Забияко А. П. Транс. Энцииклопедия эпистемиологии и философии науки. Москва, 2009. С. 999.

11. Ильин Е. П. Психология творчества, креативности, одарённости. Санкт-Петербург, 2011. С. 57-127.

12. Кришнамурти Д. Записные книжки. Мир Кришнамурти. Москва, 1999. C. 237-299.

13. Кэлвин Х., Гарднер Л. Теория личности. Москва: КСП, 1997. С. 145;

14. Ламонт К. Иллюзия бессмертия. Москва: Политиздат, 1984. С. 250. C. 176.

15. Латьенс М. Жизнь и смерть Кришнамурти. Москва: КМК, ЛТД, 1993.

16. Мурашкин М. Г. Записи 2000 года. Дніпропетровськ: СІЧ, 2006. С. 127.

17. Никонов К. Н. Бессмертие Религиоведение: энциклопедический словарь. Москва: Академический проспект, 2006. С. 109.

18. Огурцов А. П. Бессмерти. Новая философская энциклопедия. В 4т. Т.1. Москва : Мысль, 2010. С. 252.

19. Потебня А. А. О Доле и сродных с нею существах. Слово и миф. Москва : Правда, 1989. С. 472-529.

20. Прохоров А. О., Валиуллина М. Е., Габдреева Г. Ш., Гарифуллина М. М., Менделевич В. Д. Психология состояний. Москва: Изд-во «Когито-Центр», 2011. С. 594-623.

21. Пустоваров В. А. Путь судьбы. Дніпропетровськ: Пороги, 2005. С. 28.

22. Ревонсуо А. Психология сознания. Санкт-Петербург, Питер, 2013. C. 288-305. 
23. Рибо Т. Болезни личности. Опыт исследования творческого воображения. Психология чувств. Минск: Харвест, 2002. С. 326.

24. Роменець В. А. Психологія творчості. Київ: Либідь, 2004. С. 168-169.

25. Рыков А. В. Постмодернизм как «радикальный консерватизм»: проблема художественно-теоретического консерватизма и американская теория современного искусства 1960-1990-х г2. Санкт-Петербург, Алетейя, 2007. C. 148.

26. Третьяков А. В. Танатология. Религиоведение: энцииклопедический словарь. Москва: Академич. проспект, 2006. С. 1032.

27. Украӥнська народна обрядова поезія / упоряд. К. Г. Борисенко. Київ: Школа, 2006. 272 с.

28. Элиаде М. История веры и религиозных идей: от Гаутамьл Будды до триумфа христианства. Москва: Академич. проспект, 2009. С. 75.

29. Юнг К. Психологические типь. Санкт-Петербург, Ювента; Москва: Прогресс. Универс, 1995. С. 532.

30. Ясперс К. Общзая психопатология. Москва: Практика, 1997. С. 152.

31. James W. The varieties of religious experience. New York: Longman, Green, 1902. P. 389.

\section{References}

1. Averintsev, S. (2010). Mistika [Mysticism] Novaya filosofskaya entsiklopediya. In vols 4. Vol. 2. Moscow: Mysl'.

2. Adler, A. (1997). O nervicheskom kharaktere [On the nervous character]. St. Petersburg: Universitetskaya kniga.

3. Burno, M. (1989). Terapiya tvorcheskim samovyrazheniem [Therapy through creative self-expression]. Moscow: Meditsina.

4. Borysenko, K. (2006). Ukrainska narodna obriadova poeziia [Ukrainian folk ritual poetry]. Kyiv: Shkola.

5. Dubrovskiy, D. (1983). Problema ideal'nogo [The problem of the ideal]. Moscow: Mysl'.

6. Dzhems, V. (1993). Mnogoobrazie religioznogo opyta [Variety of Religious Experience]. St. Petersburg: Andreev i synovya.

7. Goncharenko, N. (1991). Genii v iskusstve $i$ nauke [Geniuses in art and science]. Moscow: Iskusstvo.

8. Guseinov, A. (2010). Schast'e [Happiness]. Novaya filosofskaya entsiklopediya. In 4 vols. vol. 3. Moscow: Mysl'.

9. Eliade, M. (2009). Istoriya very $i$ religioznykh idei: Ot Gautamy Buddy do triumfa khristianstva [The history of faith and religious ideas: from Gautama Buddha to the triumph of Christianity]. Moscow: Akademicheskii Prospekt.

10. Il'in, E. (2011). Psikhologiya tvorchestva, kreativnosti, odarennosti [Psychology of art, creativity, talent] St. Petersburg: Piter. Green.

11. James, W. (1902). The varieties of religious experience. New York: Longman,

12. Krishnamurti, D. (1999). Zapisnye knizhki [Notebooks]. Mir Krishnamurti, pp. 237-299. 
13. Kelvin, Kh., Gardner L. (1997). Teoriya lichnosti [Personality theory]. Moscow: KSP.

14. Lamont, K. (1984). Illyuziya bessmertiya [Illusion of immortality]. Moscow: Politizdat.

15. Lat'ens, M. (1993). Zhizn' $i$ smert' Krishnamurti [Krishnamurti: Life and Death]. Moscow: KMK, LTD. SICh.

16. Murashkin, M. (2006). Zapisi 2000 goda [2000 Records]. Dnipropetrovsk:

17. Nikonov, K. (2006). Bessmertie [Immortality]. Religiovedenie: Entsiklopedicheskii slovar', p. 109.

18. Ogurtsov, A. (2010). Bessmertie [Immortality]. Novaya filosofskaya entsiklopediya. In 4 vols. vol. 1. Moscow: Mysl'.

19. Potebnya, A. (1989). O Dole i srodnykh s neyu sushchestvakh [On Destiny and related beings]. Slovo i mif, pp. 472-529.

20. Prokhorov, A., Valiullina, M., Gabdreeva, G., Garifullina, M., and Mendelevich, V. (2011). Psikhologiya sostoyanii [Psychology of states]. Moscow: Kogito-Tsentr».

21. Pustovarov, V. (2005). Put' sud'by [The path of fate]. Dnipropetrovsk: Porogi.

22. Revonsuo, A. (2013). Psikhologiya soznaniya [Psychology of consciousness]. St. Petersburg: Piter.

23. Ribo, T. (2002). Bolezni lichnosti. Opyt issledovaniya tvorcheskogo voobrazheniya [Diseases of personality. Experience of studying creative imagination]. Psikhologiya chuvstv. p. 326.

24. Romenets, V. (2004). Psikhologiya tvorchosti [Psychology of creativity]. Kyiv: Lybid.

25. Rykov, A. (2007). Postmodernizm kak «radikal'nyi konservatizm»: Problema khudozhestvenno-teoreticheskogo konservatizma $i$ amerikanskaya teoriya sovremennogo iskusstva 1960-1990-kh gg [Postmodernism as "radical conservatism": The problem of artistic and theoretical conservatism and the American theory of modern art of the 1960-1990s.]. St. Petersburg: Aleteiya.

26. Tretyakov, A. (2006). Tanatologiya [Thanatology]. Religiovedenie: Entsiklopedicheskii slovar'. Moscow: Akademicheskii prospekt. p. 1032.

27. Valeri, P. (1976). Ob iskusstve [On art]. Moscow: Iskusstvo.

28. Vudvorts, R. (1981). Etapy tvorcheskogo myshleniya [Stages of creative thinking]. Khrestomatiya po obshchei psikhologii. Psikhologiya myshleniya. pp. 255-257.

29. Yaspers, K. (1997). Obshchaya psikhopatologiya [General psychopathology]. Moscow: Praktika.

30. Yung, K. (1995). Psikhologicheskie tipy [Psychological types]. St. Petersburg: Yuventa; Moscow: Izdatelskaya firma «Progress-Univers».

31. Zabiyako, A. (2009). Trans [Trans] Entsiklopediya epistemiologii i filosofii nauki. Moscow: "Kanon" ROOI "Reabilitatsiya".

(C) Мурашкін М. Г., 2018

Стаття нідійшла до редакиії: 3.09.2018 